\title{
A New Approach about Earnings Management and Audit Companies: Empirical Evidences from Brazilian Capital Market
}

\author{
Eduardo Flores $^{1}$, Joelson de Oliveira Sampaio ${ }^{2}$, L. Nelson Carvalho ${ }^{1} \&$ Fernando Chiqueto $^{1}$ \\ ${ }^{1}$ Department of Accounting, University of São Paulo, Brazil \\ ${ }^{2}$ Department of Economy, University of São Paulo, Brazil \\ Correspondence: Eduardo Flores, Department of Accounting, University of São Paulo, Brazil. E-mail: \\ eduardoflores@usp.br
}

Received: February 6, 2015

Accepted: February 27, 2015

Online Published: March 25, 2015

doi:10.5539/ibr.v8n4p59

URL: http://dx.doi.org/10.5539/ibr.v8n4p59

\begin{abstract}
The aim of this study was to evaluate whether the discretionary accruals of Brazilian public companies would reveal changes as a result of the big four firm that audits them, and whether the companies served by firms of less importance in the sector would denote different behaviors in comparison to those contracting the largest four. For this purpose was formed a sample with 7,875 observations originating from 44 quarters from the period of 1998 to 2009, emphasizing the non-inclusion of the other years due to the Brazilian IFRS harmonization. Statistical estimations were carried out based on this sample using the panel data approach. The results showed differences in the discretionary accruals regardless of the size of the audit firm, and also indicated adverse patterns between clients of the four largest firms. Thus it was established that for the Brazilian capital market, simple segregation between big four and others does not appear to make any sense, contrary to the recommendations of literature. Such benchmarking suggests that future surveys conducted in this jurisdiction, which require the use of the auditor control variable, should do so by means of the inclusion of five groups, one for each large auditing company and one for smaller audit firms.
\end{abstract}

Keywords: earnings management, big four, small audits, Brazilian capital market

\section{Introduction}

The cornerstone of earnings management surveys, hereafter referred to as EM, lies in the verification of deliberate alterations in the earnings of organizations by the managers with the intention to mislead the other stakeholders in pursuit of private gains (Schipper, 1989).

Meek and Thomas (2004) established that studies present in this literature have in the core of their analyses a reference point that would serve as stimulus to highlighted practices. These advents that drive the discretionarity presented in financial statements are classified by Watts and Zimmerman (1978) in three large groups, denominated motivational factors of EM practices, being: i) incentives from capital market; ii) incentives from contractual motivations; and iii) incentives from regulatory motivations.

More specifically, the management discussed here is established through accounting choices supposedly not aimed at a better representation of economic events, but instead converging to the aforementioned opportunities. However, it is vital to stress right from the beginning that this behavior must not be confused with cheating practices, although the determination of the tenuous line that separates one perspective from another is a complex task (Carvalho \& Murcia, 2007).

Thus it is conjectured that the inhibition of EM would be filtered by the procedures employed for purposes of validation or rejection of the accounting choices adopting, bringing in this context an irrefutable sense of importance to the role of the external auditors in the mitigation of EM.

Based on this premise, different surveys were carried out in the attempt to assess the relationship between the characteristics of audit firms and the earnings management of the audited entities (e.g. Wang \& Yang, 2012; Sahay, ZviDavis, \& Peikes, 2012; Krishnan, 2003; Balsam, Krishnam, \& Young, 2003; Becker et al., 1998; Teoh \& Wong, 1993). Aspects such as auditor independence, knowledge of the economic sector audited, career experience, professional qualifications and other perspectives stand out in such evaluations. However, there is a predilection for these studies in evaluating whether EM would have different effects on companies audited by the 
so-called big four group (PwC, EY, KPMG and Deloitte) versus the other organizations undergoing the process of appraisal of their financial statements performed by other companies from this sector, yet of a smaller size.

This dichotomy between the largest companies from the audit industry ( $\mathrm{Big} \mathrm{N}$ ) and the other organizations can be firstly observed in the manuscript of DeAngelo (1981), demonstrating a considerable innovation in the formal proposition of this survey interrelationship, as the hypothesis raised would be that small audit firms are more financially dependent on their clients, as they hold a smaller market share, consequently affecting all the necessary attributes for them to perform their role with the appropriate autonomy. However, although the logical arguments listed by the author were empirically verifiable, there are no surveys that have evaluated both groups' concentration of sales beforehand, with the exception of the proper proportions, comparing them to check which dimension would effectively demonstrate greater financial limitations, a substitute for the free exercising of their judgments regarding the economic and financial situation of their contracting parties.

Another important statement to be highlighted is that the market of large auditing firms was more disseminated in the recent past. Up to the year 2002 this industry was dominated by the giant Arthur Andersen, which was dissolved as a consequence of the scandals that occurred in the North American capital market (Borgerth, 2007). We must weigh the fact that although the scandals involving the companies Enron and WorldCom, antagonists of this episode, constitute unquestionable fraudulent procedures, these entities relied on the support of their external auditors and that nevertheless EM is not to be confused with fraud, that at the very least this big company from the auditing sector abandoned all the assumptions indispensable for the satisfactory performance of its duties, calling into question the fact whether the division between large and small audit firms really is an effective proxy for purposes of enhancing the quality of accounting information.

Finally, at the point where this discussion involves issues of a more subjective nature, based on the proposal of Almeida (2005), we discuss the tender that the auditing companies have unique, idiosyncratic and characteristic work philosophies. The fact that they occupy the same economic sector would not necessarily mean they are identical in way they execute their operating procedures. This leaves room for the creation of competitive advantages by establishing a margin for them to develop their a particular way to do their work, a modus operandi, specialization in a particular field of activity, and other factors that would distinguish them from one another. To associate such organizations according to size would be to accelerate a mistaken perception that the work developed by the big four firms is of a fungible nature, i.e., regardless of who carries out this work, verification by the contracting parties and by the users of the financial statements would be the same, a situation similar to the condition of a commodity.

In the above context, this study can be synthesized in the following survey question: do discretionary accruals, proxy of earnings management, of Brazilian public companies, undergo changes owing to the big four firm that serves them? To this end, 364 Brazilian public companies were evaluated covering the period from 1998 to 2009 in order of quarterly data, with a total sample of 7,865 observations. Statistical estimations were performed based on the panel data approach so as to assess the isolated effect of earnings management to the detriment of each one of the companies from the large audit groups mentioned. The years 2010 to 2013 were not included in the sample because of the process of adopting international accounting standards (IFRS) in Brazil, seeking, above all, not to bias the statistical findings presented. We should emphasize that at no time was this survey aimed at establishing hierarchy between such organizations, or at exposing them to marketing constraints. Hence the decision was made to encrypt their names upon the presentation of results, so as to temporarily preserve the companies' images. Further methodological details are presented in section 3.

\section{Theoretical Framework and Development of Hypotheses}

\subsection{The Relevance of the External Audit in the Mitigation of Earnings Management}

Different conceptions of EM indicate that this practice originates from the imposition of the judgment of managers on the financial statements, through accounting choices, aiming to report results that bias the interpretation of the stakeholders in the business of an entity, favoring them with the generation of private gains versus the informational imbalance promoted by these figures (e.g. Schiper, 1989; Healy; Weahlen, 1999; Scott, 2003; Riahi-Belkaoui, 2005).

Watts and Zimmerman (1978) suggested that the contractual relations between companies and their stakeholders would tend to stimulate EM when the cost of the practice appears lower than the benefits observed by the managers, is a kind of trade-off analysis. We must emphasize that according to Fields, Lys and Vicent (2001), not all accounting decisions are prompted by the pretext of managing earnings, and the term EM could transcend such choices. However, the selection of procedures, whether in revenue recognition, measurement or evidencing aimed at particular patterns of earnings would be in line with the concept presented in the preceding paragraph. 
In this spectrum audit has a particular importance, as the purpose of this mechanism is supposedly to ensure that financial statements to the external users of these accounting numbers are delivered with reliability that represent the best characterization of the economic and financial events that have impacted the companies, reducing the incentives that the managers would have to manipulate earnings (Wallace, 1980; Tie, 1999; Chambers, 1999). For example, Kinney and Martin (1994) found signs that financial audit considerably reduces the bias present in the net income of audited companies, while Hirst (1994) ascertained that auditors have accentuated sensitivity in the verification of earnings management, which would inhibit the publication of overstated profits.

Another important perspective concerning the relevance of auditors is established in the argument that their performance would reduce agency costs, consistent with the prerogatives of the agency theory from Jensen and Meckling (1976). Boyton, Johson and Kell (2002), when reading the independent auditor's report, stakeholders seek assurance with regards to the relevance and reliability of such numbers; hence this item would affect the risk perception of such individuals and therefore the returns expected in the allocation of financial resources.

\subsection{Size of the Auditing Company as a Proxy of Quality of the Work Performed}

Becker et al (1998) emphasize that while audit is considered a control mechanism against managerial discretion is concerned its value added is expected to depend on the quality of the work carried out. In broad sense this quality can be observed by means of the independence construct, which would assign autonomy to the auditors for identification and reporting involving questionable accounting methods used by their clients (Watts \& Zimmerman, 1978; DeAngelo, 1981).

According to Ebrahim (2001) the most common way of empirically assessing audit quality is by means of segregation between large companies from the sector and the other organizations situated in this niche. Different surveys were developed with the purpose of evaluating whether this distinction produce observable effects. DeAngelo (1981) noted that large auditing companies have greater incentives to report questionable accounting practices, given the dissemination of their client portfolios. Nichols and Smith (1983) evaluated whether the credibility of these companies would somehow favor them in exchanges performed by the demanders of this service, thus seeking a perception of credibility from the perspective of the contracting parties. Teoh and Wong (1993) observed the earnings response coefficient for companies audited by larger organizations compared to the others, thus tying the idea that earnings reported by big-four clients would tend to be more timely in the incorporation of material economic events. DeFond and Jiambalvo (1993) analyzed whether companies audited by large firms had behaviors linked to EM at different levels from the organizations that had their financial statements evaluated by auditors from small organizations. Sahay, ZviDavis and Peikes (2012) evaluated whether the move from large to small audit firms is somehow connected to EM practices.

Another fundamental argument for division between big four and non-big four, according to Dopuch and Simunic (1982), is that large corporations from this sector would be prone to a higher image risk due to problems with their reputation than their small competitors. Hence these companies would enhance the quality of their work, seeking not to undergo market sanctions resulting from these aspects. This assumption demonstrates a certain controversy when we assess the case of the company Arthur Andersen, since although Blouin, Grein and Rountree (2007) formalize the impression that the generalized dispersion of the clients of this audit firm occurred due to the organization's involvement in the Enron case, thus confirming a reputation impact, it cannot be said that the defunct company's behavior was protected by its brand.

Nonetheless, a review of literature demonstrates valid arguments to believe in greater independence among large firms from the industry in comparison to their competitors, and it is emphasized that the organizational dynamics of a big four firm divides its departments by areas, attributing to each one of these at the very least one partner, who will have a larger or smaller team depending on the complexity and size of their sector. To this effect, the four largest auditing companies would function as large clusters of teams with the purpose of sharing the brand and not necessarily the financial performance.

Based on this scenario it would be possible to conjecture that the financial dependence of the big four firms in relation to their clients increases with the division into increasingly smaller administrative units, as the weight of the contracting parties would now be considered in the portfolio of the industry and no longer in that of the company. Hence it logically follows that the measure of quality, substitute of independence, is impacted.

Another factor that would corroborate the decline of the dichotomy between large and small auditing companies is the attribution of commercial demands to the professionals belonging to these departments, since as work time is a scarce resource and as the partners, directors and managers of large audit firms have to divide their availability between work of a technical nature and the prospecting of new business opportunities, it would fall to less senior professionals to handle the operational development of the reviews required to issue the opinion, 
which although reviewed by their superiors, could nonetheless have diminished in quality due to their absence at the time of the effective test validation process.

\subsection{Distinctions between Large Audit Firms in the Brazilian Market}

Judging from the information available on the website of the Brazilian Securities Commission - CVM, it could be seen that the group formed by the big four firms, over the course of the studied period from 1998 to 2009, was responsible for the auditing of approximately $60 \%$ of the financial statements of public companies in Brazil. It is emphasized that during the period from 1998 to 2002, there was opinions issued by Arthur Andersen and that although this company had been largely absorbed by Deloitte in the year 2002, the decision was made not to add such observations to the balance of the acquirer, as it was not possible to establish whether the organizations present in the sample continued with the new firm or not.

The figures are even more noteworthy if we consider that 90 different audit firms were found during the years analyzed. By subtracting the largest four, it is possible to establish that the entire remaining balance was covered by 86 smaller companies, which would result in an arithmetic mean, for purposes of a more superficial analysis, of less than $0.5 \%$ of the sample for each company.

As regards the market share of the big four firms, it was verified that PwC led the group with a total 422 financial statements audited, followed by Deloitte with 415 clients, Ernst \& Young with 261 companies and finally, KPMG with 254. It is emphasized that the auditors in charge at the end of each year were taken into consideration, for which reason the total sum of observations surpasses the aforementioned number of companies.

Another important focus of analysis that is in line with the specialization of audit firms is their participation in specific economic sectors. In this regard, the figures disclosed in the foregoing paragraph were segregated according to the industries established by the Economatica ${ }^{\circledR}$ databases program, in which 18 specific sectors and one residual category designated others, are formed. See Table 1.

Table 1. Market share of audit firms in specific industries

\begin{tabular}{|c|c|c|c|c|c|c|c|c|c|c|c|c|}
\hline \multirow{2}{*}{$\begin{array}{c}\text { Industries } \\
\text { Agriculture }\end{array}$} & \multicolumn{2}{|c|}{ Deloitte } & \multicolumn{2}{|c|}{ EY } & \multicolumn{2}{|c|}{ KPMG } & \multicolumn{2}{|c|}{ PWC } & \multicolumn{2}{|c|}{ Others } & \multicolumn{2}{|c|}{ Total } \\
\hline & - & - & 3 & $1 \%$ & - & - & 2 & $0 \%$ & 7 & $1 \%$ & 12 & $1 \%$ \\
\hline Food and Beverage & 18 & $4 \%$ & 26 & $10 \%$ & 22 & $9 \%$ & 13 & $3 \%$ & 90 & $10 \%$ & 169 & $8 \%$ \\
\hline Trade & 30 & $7 \%$ & 25 & $10 \%$ & - & - & 28 & $7 \%$ & 52 & $6 \%$ & 135 & $6 \%$ \\
\hline Construction & 24 & $6 \%$ & - & - & 2 & $1 \%$ & 24 & $6 \%$ & 80 & $9 \%$ & 130 & $6 \%$ \\
\hline Electronics & 3 & $1 \%$ & 7 & $3 \%$ & 13 & $5 \%$ & 10 & $2 \%$ & 18 & $2 \%$ & 51 & $2 \%$ \\
\hline Electric Power & 66 & $16 \%$ & 18 & $7 \%$ & 40 & $16 \%$ & 11 & $3 \%$ & 37 & $4 \%$ & 172 & $8 \%$ \\
\hline Machinery & 8 & $2 \%$ & 11 & $4 \%$ & 14 & $6 \%$ & - & - & 10 & $1 \%$ & 43 & $2 \%$ \\
\hline Mining & 13 & $3 \%$ & 5 & $2 \%$ & 3 & $1 \%$ & 14 & $3 \%$ & 3 & $0 \%$ & 38 & $2 \%$ \\
\hline Minerals & 9 & $2 \%$ & - & - & - & - & 13 & $3 \%$ & 13 & $1 \%$ & 35 & $2 \%$ \\
\hline Others & 38 & $9 \%$ & 24 & $9 \%$ & 35 & $14 \%$ & 50 & $12 \%$ & 166 & $19 \%$ & 313 & $14 \%$ \\
\hline Paper and Cellulose & 14 & $3 \%$ & 10 & $4 \%$ & 10 & $4 \%$ & 15 & $4 \%$ & 18 & $2 \%$ & 67 & $3 \%$ \\
\hline Oil and Gas & 5 & $1 \%$ & 9 & $3 \%$ & 5 & $2 \%$ & 30 & $7 \%$ & 13 & $1 \%$ & 62 & $3 \%$ \\
\hline Chemistry & 34 & $8 \%$ & 8 & $3 \%$ & 26 & $10 \%$ & 40 & $9 \%$ & 35 & $4 \%$ & 143 & $6 \%$ \\
\hline Iron and Steel & 32 & $8 \%$ & 25 & $10 \%$ & 22 & $9 \%$ & 86 & $20 \%$ & 109 & $12 \%$ & 274 & $12 \%$ \\
\hline Software & 4 & $1 \%$ & 4 & $2 \%$ & - & - & 1 & $0 \%$ & - & - & 9 & $0 \%$ \\
\hline Telecom & 40 & $10 \%$ & 30 & $11 \%$ & 11 & $4 \%$ & 25 & $6 \%$ & 35 & $4 \%$ & 141 & $6 \%$ \\
\hline Textiles & 55 & $13 \%$ & 19 & $7 \%$ & 14 & $6 \%$ & 27 & $6 \%$ & 116 & $13 \%$ & 231 & $10 \%$ \\
\hline Transport & 13 & $3 \%$ & 12 & $5 \%$ & 10 & $4 \%$ & 16 & $4 \%$ & 11 & $1 \%$ & 62 & $3 \%$ \\
\hline Vehicles and Parts & 9 & $2 \%$ & 25 & $10 \%$ & 27 & $11 \%$ & 17 & $4 \%$ & 71 & $8 \%$ & 149 & $7 \%$ \\
\hline Total & \multicolumn{2}{|c|}{415} & \multicolumn{2}{|c|}{261} & \multicolumn{2}{|c|}{254} & \multicolumn{2}{|c|}{422} & \multicolumn{2}{|c|}{884} & \multicolumn{2}{|c|}{2,236} \\
\hline \% Total & \multicolumn{2}{|c|}{$19 \%$} & \multicolumn{2}{|c|}{$12 \%$} & \multicolumn{2}{|c|}{$11 \%$} & \multicolumn{2}{|c|}{$19 \%$} & \multicolumn{2}{|c|}{$40 \%$} & \multicolumn{2}{|c|}{$100 \%$} \\
\hline
\end{tabular}

Source: Author (2014). 
Note that Deloitte and PWC demonstrated greater diversity of clients when compared to the other two audit firms, as both firms are only absent in one industry each, respectively those of agriculture and fishing and industrial machinery. The other two companies were absent in two industries for EY and four for KPMG.

The information contained in Table 1 also indicates the volume of representativeness of the sectors in the total group of public companies served by each one of the large companies. The highest concentration was verified in the interrelationship between PWC and the iron and steel industry (20\%), respectively followed by the percentage relationship between the electric power niche and the companies Deloitte and KPMG (both 16\%). At EY the highest concentration was observed in the telecommunications field (11\%).

Broadly speaking it is possible to visualize a certain level of proximity between the figures of the companies Deloitte and PWC, both in absolute values and in percentage terms. Similarity can also be observed between EY and KPMG. However, the first companies mentioned are not similar to the latter two in volume of activities, and it is not possible to infer that the four organizations have comparable market reach. It is also emphasized that by including the other companies and comparing them to the big four firms, this relationship became even more dissimilar, as the sums now seen separately reveal that none of the large audit firms surpasses the total volume of the smaller companies.

In this regard, although it is acknowledged that the four largest auditing companies are unequivocally significant as refers to the industry in which they operate, it is conjectured whether different work patterns exist, together with the possibility of differentiated levels of imposition concerning the necessary autonomy for satisfactory execution of the financial statement examinations, resulting in a scenario in which the auditors have less autonomy for the free execution of their work. Thus the audited companies could feel encouraged to carry out more discretionary accounting practices, depending on the big four company that serves them, impacting earnings with higher levels of subjectivism by default, thus constituting earnings management practices

Based on the verified literature review, and on the conclusions reached after this process, the hypotheses tested in this study were:

Hypothesis 1: There are statistically significant differences in the discretionary accruals (earnings management proxy) of Brazilian public companies according to the big four firm that audit them.

Hypothesis 2: The differences in the discretionary accruals (earnings management proxy) of public companies will not be statistically significant if we compare the group served by small audit firms with each one of the big four firms.

\section{Methodology}

\subsection{Sample}

Information for the period from 1998 to 2009 was gathered from the Brazilian capital market using the Economatica ${ }^{\circledR}$ database in an attempt to achieve a sample that would allow the above mentioned hypotheses to be tested. The respective information originated from a quarterly periodic management (44 quarters) with the intention of capturing more timely changes in the behavior of discretionary accruals, as suggested by Giroux (2011). The data collection was limited to the year 2009, due to the IFRS - international accounting standards harmonization. Even with the insertion of a dichotomous variable designed to segregate the periods, it was considered possible for the results to undergo interventions arising from this peculiarity, which could generate bias in the conclusions and consequent error in the study findings.

A total of 9,873 observations were initially obtained from 416 different companies. After excluding inconsistent items, and eliminating data originating from financial institutions and insurers as well, which were dropped from the sample due to the specificity of the field of activity and the impact caused on the accounting numbers, an informational base of 7,875 lines remained, composed of 364 different organizations. It is also emphasized that the procedure known as winsorization was carried out based on the indications of Yale and Forsythe (1976). This procedure consists of the elimination of more extreme values from the sample, in order to reduce the presence of outliers and make the information more homogenous.

\subsection{Estimation of Discretionary Accruals}

A notable restriction of EM studies lies in the models employed to obtain discretionary accruals, since these do not have objective verification. According to Dechow et al. (2012) these techniques have low explanatory power and are sometimes poorly specified.

Different proposals have been submitted to mitigate these problems (e.g. Jones, 1991; Dechow, Sloan, \& Sweeney, 1995; Kang \& Sivaramakrishnan, 1995). Yet all these share the same intrinsic purpose: to segregate the 
portion of accruals considered discretionary from the others. It is interesting to mention that each paper submitted in this context reports the appearance of some new dimension which frequently reveals itself as superior to the previous models.

Having recognized this limitation and seeking to reduce the implications arising from this weak point, 84 studies along EM lines were reviewed, 50 of which were published in international periodicals and 34 in national academic journals, noting that the model employed most often in the surveys evaluated was the adaptation of the original Jones (1991) model by Dechow, Sloan and Sweeney (1995), called Modified Jones Model - MJM. Although the issue presented is recognized, this study was not designed to discuss the robustness of the techniques reported here. For this purpose, the authors suggest the surveys of Dechow and Dichev, (2002), McNichols (2002), Islam, Ali and Ahmad (2011).

MJM (1995) is presented as follows in equation 1:

$$
\frac{A T_{i t}}{A_{i t-1}}=\alpha \frac{1}{A_{i t-1}}+\beta_{1} \frac{\Delta R E V_{i t-} \Delta R E C_{i t}}{A_{i t-1}}+\beta_{2} \frac{P P E_{i t}}{A_{i t-1}}+\varepsilon_{i t}
$$

In which are the total accruals per company in period $t$, calculated through the following expression: $\Delta$ Current Assets $_{\text {it }}-\Delta$ Current Liabilities $_{\text {it }}-\Delta$ Cash $_{\text {it }}+\Delta$ Short-Term Debts $_{\text {it }}$ (Allen, Larson, \& Sloan, 2010). Item denotes the lagged total assets at a particular time, are the variations of total revenues, refer to the variations of total receivables and corresponds to property, plant and equipment. The discretionary accruals are obtained by means of the error term it, hereafter designated DA.

\subsection{Model and Statistical Technique for Hypotheses Testing}

The model employed to test the established hypotheses was developed from the term DA calculated in the previous subsection. It is emphasized that preceding papers recommend the use of control items, aiming to expurgate from the statistical coefficients effects resulting from adverse features of the sample (e.g., McNichols, 2000; Dechow, Richardson, \& Tuna, 2003; Jones, Krishnan, \& Melendrez, 2008). The inclusion of such items allows not only a robustness enhancement of the findings of EM papers, but also adds the legitimation of studies developed in this sector, as it evidences the previous concern in depurating the database with discrepancies that cannot be subsequently controlled by statistical models (Giroux, 2011). Both the variables of intention of the empirical model and the control variables are expressed in Equation 2:

$$
\begin{gathered}
D A_{i t}=\alpha+\beta_{1} A u d_{-} 1_{i t}+\beta_{2} A u d_{-} 2_{i t}+\beta_{3} A u d_{-} 3_{i t}+\beta_{4} A u d_{-} 4_{i t}+\beta_{5} O t h_{-} A u d_{i t}+\beta_{6} R O A_{i t}+\beta_{7} B T M_{i t}+ \\
\beta_{8} I N D_{i t}+\beta_{9} L E V_{i t}+\varepsilon_{i t}
\end{gathered}
$$

Where:

$A u d \_1_{i t} / A u d \_2_{i t} / A u d \_3_{i t} / A u d \_4_{i t}=$ binary term representing each one of the big four firms by client (i) and period of time (t).

$O t h \_A u d_{i t}=$ binary variable representing smaller audit firms by client (i) and period of time (t).

$R O A_{i t}=$ Return On Asset included to reduce the heterogeneity of returns of the firms that make up the sample, obtained by means of the net income divided by total assets (Kothari et al., 2005).

$B T M_{i t}=$ Book to Market seeking to mitigate the effect inherent to the discrepancies generated by market expectations involving the operating performance of the firms, formed by the ratio between book value and market value of the companies (Larcker \& Richardson, 2004; Ohtman \& Zeghal, 2006).

$I N D_{i t}=19$ industries from the Economatica database included to settle the accounting differences resulting from the different niches of activity of the organizations that make up the sample (Watts \& Zimmerman, 1978).

$L E V_{i t}=$ Financial leverage inserted in the model with the intension of controlling the behavior of firms with a higher demand for third party capital, obtained by means of the formula: [Net Income/Net Worth]/[Income before interest and income tax/Total Assets] (Coelho \& Lopes, 2007).

Based on the above mentioned terms, more specifically on the items of concentration of the model, the decision was made to encrypt the names of the big four firms, transcribing them in generic terms, particularly so as not to derive from this study any supposed qualitative staggering between the organizations that form this group.

As refers to the use of the statistical technique to estimate and obtain the results, according to the longitudinal characteristic of the sample components, panel data modeling was employed. According to Wooldridge (2010) a set of panel data has dimensions both of cross section and of time series, given that the same individual (i) is observed over a period $(t+k)$. Diggle et al. (2002) stress that, this data assessment format enables investigations 
into changes in the variable response to an individual over time and the fluctuations between different sample components, increasing the quality of the causality interpretations. In a supplementary sphere, the use of the panel data technique helps to control the sample heterogeneity, produces less multicollinearity and adds to data variability, making it possible to gain more efficient estimators (Marques, 2000; Fávero, 2013).

\section{Results}

The results shown were obtained through the R-Project software. The statistical trends of MJM (1995) are demonstrated first. This model was initially employed in order to obtain the discretionary accruals. The findings originating from the application of the model expressed in Equation 2, which was effectively used to test the hypotheses raised, are revealed in the following subsection.

\subsection{Obtainment of Discretionary Accruals Using MJM (1995)}

As described in item 3.2, MJM is composed of three explanatory variables, which are quoted as estimators not liable to the action of earnings management, hence considered substitutes of non-discretionary accruals. The descriptive measures of these terms together with the total accruals are presented below.

Table 2. Descriptive statistics of the variables that compose the modified jones model

\begin{tabular}{ccccccc}
\hline Variables & Mean & Median & Standard Deviation & Minimum & Maximum & Obs \\
\hline AT & -0.0443 & -0.0395 & 0.0858 & -0.5741 & 0.4034 & 7875 \\
1st Var. MJM & 0.0000 & 0.0000 & 0.0000 & 0.0000 & 0.0002 & 7875 \\
2nd Var. MJM & 0.0281 & 0.1899 & 0.5721 & -5.7306 & 3.2484 & 7875 \\
3rd Var. MJM & 0.0144 & 0.0012 & 0.2055 & -0.9470 & 15.7189 & 7875 \\
\hline
\end{tabular}

Source: Authors (2014).

It is possible to observe in Table 2, with the exception of the first variable of MJM, that the items exhibit considerable standard deviations. This accentuation can be partly attributed to the presence of companies with different sizes in the sampling, which consequently impacts the generation of greater variability involving the actual values of each item, comparing them to the computed arithmetic means. Another factor to be considered in this criterion lies in the presence of companies from different industries, which itself could already produce impacts on the observations. Based on these two factors, inclusion in the model used to test the hypotheses of the terms ROA and Industries, whose purpose is to reduce this heterogeneity, is justified.

As regards the first term of the model, note that practically all the computed measurements are close by zero. This results from the way in which this variable is obtained, where the number one is divided by the total assets of each company lagged in a period. According to Jones (1991) the inclusion of this term is aimed at reducing the sample asymmetry.

The correlations of the variables that constitute the model were calculated prior to its regression, with the intention of assessing possible multicollinearity problems between them. According to the results obtained, the three explanatory variables did not present association indices above 0.50 , which indicates low probability concerning the existence of this problem (Kennedy, 1998).

The results obtained by regression of MJM based on the panel data technique are presented after this. The Chow and Hausmann tests were conducted in order to establish the most coherent format for obtaining the parameters (Pooling, Fixed or Random Effects). According to the validations, the best results obtained originated from the random effects model. According to Duarte, Lamounier and Takamatsu (2007) the random effects model has the same suppositions as the fixed effects model, i.e., it is considered that the intercept varies from one individual to the next, yet not over time, and that the response parameters are fixed for all the individuals and in all the periods of time, hence the difference between both models occurs in the treatment of the intercept, in view of the fact that while the fixed effects model treats the intercepts as constant, the random effects model considers them random variables. 
Table 3. Panel data regression with random effects for variable AT

\begin{tabular}{|c|c|c|c|c|c|}
\hline \multicolumn{6}{|c|}{ Modified Jones Model (1995): $\frac{D A_{i t}}{A_{i t-1}}=\alpha \frac{1}{A_{i t-1}}+\beta_{1} \frac{\Delta R E V_{i t-} \Delta R E C_{i t}}{A_{i t-1}}+\beta_{2} \frac{P P E_{i t}}{A_{i t-1}}+\varepsilon_{i t}$. } \\
\hline Variables & Coefficients & Standard Error & t-value & p-value & \\
\hline Intercept & $(0.0407)$ & 0.0023 & -17.9815 & 0.000 & $* * *$ \\
\hline 1st $\operatorname{Var} \operatorname{MJM}(\alpha)$ & $(608.50)$ & 120.85 & -5.0363 & 0.000 & $* * *$ \\
\hline 2nd Var MJM $(\beta 1)$ & 0.0002 & 0.0016 & 0.1421 & 0.8870 & \\
\hline 3rd Var MJM $(\beta 2)$ & $(0.0173)$ & 0.0045 & -3.8328 & 0.000 & $* * *$ \\
\hline F-statistic $=23.2295$ & $\mathrm{~N}=7,875$ & Adjusted $R^{2}=0.0088$ & & $<0.0000$ & $* * *$ \\
\hline
\end{tabular}

Note. Significance levels: ‘*’ $10 \%$; ‘**' $5 \%$; ‘***’ $1 \%$.

Source: Authors (2014).

The results obtained with MJM were consistent with previous studies (e.g. Ohtman \& Zeghal, 2006; McNichols, 2000; Dechow et al., 1995), demonstrating high statistical significance of the explanatory variables (p-value $<0.000)$ in conjunction with a low R2 (0.0088). Although other versions of MJM are being presented with an extended format, i.e., considering the inclusion of control terms already in this step, it is emphasized that according to Gioelli, Carvalho and Sampaio (2013), the means and standard deviations for the original and expanded versions of this technique do not vary a great deal, which would consequently not justify the loss of degrees of freedom with the insertion of items that would not add the explanatory quality of the discretionary accruals, error term of the model, used as dependent variable in the model shown in Equation 2.

\subsection{Descriptive Statistics}

Different evaluations of the behavior of variable DA were carried out prior to the estimation of the model applied to the hypotheses raised (see Equation 2). The first of these verifications consisted of its graphic analysis based on each one of the audit companies that are leaders of the sector, as well as the set of observations from companies audited by smaller organizations (Graph 1), according to the quarterly computation. It can be seen that the mean of the discretionary accruals between audit firms did not undergo very large variations. It is stressed that the companies audited by the big four firms identified as Aud_1, reveal a higher general mean than the other companies, which would characterize more discretionary accounting practices. As regards the amplitude between minimum and maxim observation, the companies served by various auditors (Out_Aud) were seen to demonstrate greater variability, which is not surprising since this group contains more than 880 companies-year, which is double the group coming second. It is also emphasized that Aud_3 and Aud_4 revealed practically equal means in the sum of the quarters, while lower numbers than the other competitors were identified in Aud_2.

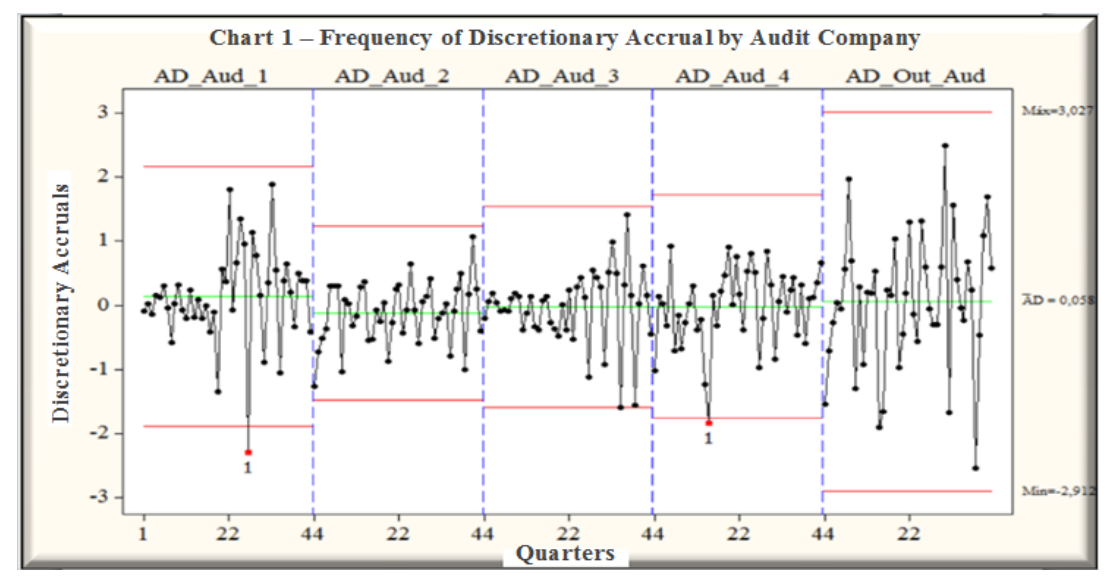

Figure 1. Frequency of discretionary accrual by audit company

This evaluation allows us to observe a prior existence of different EM trends between the companies present in the sample, particularly when considered in view of their auditors, suggesting signs of different behaviors 
between Big Four clients. For example, the Aud_1 stratum resembles that of Oth_Aud more closely than the others. The central trend and DA item variation measurements were also calculated, following the subdivision established above, together with the explanatory items of the model (Table 4).

Table 4. Descriptive statistics of the component variables of the model employed in the tests

\begin{tabular}{ccccccc}
\hline Variables & Mean & Median & Standard Deviation & Minimum & Maximum & Obs \\
\hline DA_AUD_1 & 0.1345 & 0.1383 & 0.7396 & -2.2974 & 1.8961 & 1626 \\
DA_AUD_2 & -0.1236 & -0.0670 & 0.4871 & -1.2762 & 1.0732 & 958 \\
DA_AUD_3 & -0.0276 & 0.0629 & 0.5642 & -1.5927 & 1.4103 & 1503 \\
DA_AUD_4 & -0.0200 & 0.0829 & 0.6043 & -1.8438 & 0.9190 & 910 \\
DA_Oth_Aud & 0.0577 & 0.1734 & 1.0488 & -2.5463 & 2.5025 & 2878 \\
DA* & 0.0005 & 0.0012 & 0.0805 & -0.5179 & 0.9195 & 7875 \\
LEV & 2.9191 & 1.1834 & 26.74 & -412.38 & 869.60 & 7875 \\
BTM & 1.5735 & 1.0000 & 16.04 & -283.70 & 852.60 & 7875 \\
ROA & 0.0034 & 0.0153 & 0.1339 & -3.3796 & 2.0975 & 7875 \\
\hline
\end{tabular}

Note. *General measures of the variable without the quarterly sum.

Source: Authors (2014).

The values obtained by segregation of the DA variable confirm the perceptions reached by means of the analysis of Chart 1. It is not only the means that diverge between the companies but also the other indicators. In observing the dependent term without the respective individualization, it can be noted that this term is highly influenced by the sample heterogeneity, denoting an absolutely different mean. The other control terms (LEV, BTM and ROA) share the same variance perspective.

Although the term industries is relevant for a better estimation of the model coefficients, the presentation of the descriptive statistics by sector was deemed improper, since the actual insertion of this dummy would already cover the intended functional aspects. To assess the intensity and direction of relations between variables, the participants calculated Pearson's correlation measures as well as the respective p-values (Table 5).

Table 5. Correlation matrix

\begin{tabular}{|c|c|c|c|c|c|c|c|}
\hline & DA_Aud_1 & DA_Aud_2 & DA_Aud_3 & DA_Aud_4 & DA_Oth_Aud & FL & BTM \\
\hline \multirow[b]{2}{*}{ DA_Aud_2 } & 0.9654 & & & & & & \\
\hline & *** & - & & & & & \\
\hline \multirow{2}{*}{ DA_Aud_3 } & 0.9932 & 0.9943 & & & & & \\
\hline & $* * *$ & $* * *$ & - & & & & \\
\hline \multirow{2}{*}{ DA_Aud_4 } & 0.9928 & 0.9941 & 0.9988 & \multirow[b]{2}{*}{ - } & & & \\
\hline & $* * *$ & $* * *$ & $* * *$ & & & & \\
\hline \multirow{2}{*}{ DA_Oth_Aud } & 0.9484 & 0.9571 & 0.9916 & 0.9911 & \multirow{2}{*}{ - } & & \\
\hline & $* * *$ & $* * *$ & $* * *$ & $* * *$ & & & \\
\hline \multirow{2}{*}{ LEV } & 0.6368 & 0.6135 & 0.7056 & 0.1721 & 0.7217 & \multirow[b]{2}{*}{ - } & \\
\hline & $* * *$ & $* * *$ & $* * *$ & $* * *$ & $* * *$ & & \\
\hline \multirow{2}{*}{ BTM } & 0.0123 & 0.2723 & 0.0018 & 0.0585 & 0.0058 & 0.0000 & \multirow{2}{*}{-} \\
\hline & 0.2328 & $* * *$ & 0.0384 & $* * *$ & 0.1156 & $* * *$ & \\
\hline \multirow{2}{*}{ ROA } & 0.0004 & 0.0004 & 0.0559 & 0.0000 & 0.0000 & 0.0000 & 0.0000 \\
\hline & 0.0086 & 0.0097 & $* *$ & $* * *$ & $* * *$ & $* * *$ & $* * *$ \\
\hline
\end{tabular}

Note. *** Significant at $1 \%$; ** Significant at $5 \%$.

Source: Authors (2014). 
The dependent variable (DA) segregated between the audit firms presents autocorrelation with financial leverage (LEV), revealing the importance of this item as a control term, given that companies more dependent on third-party capital are expected to tend to manage their earnings more (see Watts \& Zimmerman, 1986). In relation to BTM and ROA, no prominent findings were obtained. Finally, attention is drawn to the association between the correlations of DAs, comparing them between audit firms. An almost perfect and extremely significant correlation is noted between them as an evident sign that the discretionary of accounting practices takes in consideration other factors and not just the size of the auditor.

\subsubsection{Estimation of the Empirical Model}

Different estimations were performed based on the variables from Equation 2. For all the regressions performed the recommendation of the random effects model was confirmed as being the provider of the best statistical parameters.

The initial step was the regression of the model with the binary variables representing the four largest auditing companies, comparing these companies with the smaller firms. In this model, it was noted that of the nineteen industries included for control of sample discrepancies, only two proved statistically significant: the construction and telecommunications sectors. Other tests were conducted and only these two remained relevant as control variables. Accordingly, in order to ensure a carefully controlled balance of results, the other economic niches were not included in the test method.

Table 6 shows the results obtained with the regression of the main model, in which the variance of the discretionary accruals of Brazilian listed companies, served by large audit firms, is compared with companies that also trade their instruments, yet are audited by small firms from the sector. This is followed by an evaluation of the isolated effect of the same variance, yet this time considering each one of the big four companies separately, i.e., comparing them with all the other firms from the sector.

Table 6. Regression of big four models versus big four and others

\begin{tabular}{ccccccc}
\hline Variables & Big Four & Aud_1 & Aud_2 & Aud_3 & Aud_4 & Oth_Aud \\
\hline Intercept & $0.0030^{*}$ & 0.0005 & 0.0015 & 0.0013 & 0.0014 & -0.0002 \\
Aud_1 & 0.0000 & 0.0026 & N.A. & N.A. & N.A. & N.A. \\
Aud_2 & $-0.006^{* *}$ & N.A. & $-0.0046^{*}$ & N.A. & N.A. & N.A. \\
Aud_3 & $-0.0052^{*}$ & N.A. & N.A. & -0.0016 & N.A. & N.A. \\
Aud_4 & -0.0032 & N.A. & N.A. & N.A. & -0.0037 & N.A. \\
Oth_Aud & N.A. & N.A. & N.A. & N.A. & N.A. & 0.0031 \\
FL & -0.0000 & -0.0000 & -0.0000 & -0.0000 & -0.0000 & -0.0000 \\
BTM & $0.0001 *$ & $0.0001 *$ & $0.0001 * *$ & $0.0001 *$ & $0.0001 *$ & $0.0001 *$ \\
ROA & $0.0084^{* * *}$ & $0.0823 * * *$ & $0.0832^{* * *}$ & $0.00832^{* * *}$ & $0.0835^{* * *}$ & $0.0085^{* * *}$ \\
Const. Ind. & $0.0192^{* * *}$ & $0.0205^{* * *}$ & $0.0200^{* * *}$ & $0.0205^{* * *}$ & $0.0201 * * *$ & $0.0198^{* * *}$ \\
Telecom Ind. & $-0.0279 * * *$ & $-0.0286^{* * *}$ & $-0.0278^{* * *}$ & $-0.0284^{* * *}$ & $-0.0285^{* * *}$ & $-0.0279^{* * *}$ \\
\hline Adjusted R & $0.0339^{2 * * *}$ & $0.0333^{* * *}$ & $0.0335^{* * *}$ & $0.0332^{* * *}$ & $0.0333^{* * *}$ & $0.0334^{* * *}$ \\
F-Statistic & 30.7617 & 45.1788 & 45.4202 & 45.0253 & 45.2392 & 45.2923 \\
\hline
\end{tabular}

Note. *** Significant at 1\%;** Significant at 5\%; $*$ Significant at $10 \%$.

Source: Authors (2014).

The results of the Big Four column denote that only the variables Aud_2 and Aud_3 revealed statistically significant differences, respectively $-0.006^{* *}$ and $-0.0052^{*}$. The variables representing the firms Aud_1 and Aud_4 did not present signs of estimated means different from the Out_Aud term. This inference allows us to emphasize that the division between the four largest audit firms and other smaller firms, does not appear to make sense in the Brazilian capital market, as the behavior of the DAs of half of this group is statistically identical to that of clients of smaller companies. This finding gains robustness when we evaluate the results of the unambiguous models, which consider only the effect of the variance of the dependent term against all the other 
competitors. With special emphasis on Aud_2, in which an estimated parameter $\left(-0.0046^{*}\right)$ different from all the other observations of the sample, including those of the other Big Four firms, was found. As concerns the other audit firms, the non-verification of significance upon the performance of the test that considers it the primary factor (0.0031), reinforces the idea that in general sample terms, there are no findings that allow us to make the segregation advocated by the literature for the Brazilian capital market.

Table 7 compares the effect of the variance of the DAs of each Big Four firm with the other direct competitors, i.e., only the other three largest firms. The Oth_Aud term was included in conjunction in the model for such a purpose.

Table 7. Estimation of the big four versus big four models

\begin{tabular}{|c|c|c|c|c|}
\hline Variables & Aud_1 & Aud_2 & Aud_3 & Aud_4 \\
\hline Intercept & -0.0016 & 0.0005 & 0.0004 & -0.0001 \\
\hline Aud_1 & $0.0046 *$ & N.A. & N.A. & N.A. \\
\hline Aud_2 & N.A. & -0.0036 & N.A. & N.A. \\
\hline Aud_3 & N.A. & N.A. & -0.0027 & N.A. \\
\hline Aud_4 & N.A. & N.A. & N.A. & -0.0002 \\
\hline Oth_Aud & $0.0045^{*}$ & 0.0024 & 0.0026 & 0.0030 \\
\hline FL & -0.0000 & -0.0000 & -0.0000 & -0.0000 \\
\hline BTM & $0.0001 *$ & $0.0001 *$ & $0.0001 *$ & $0.0001 *$ \\
\hline ROA & $0.0842 * * *$ & $0.0845^{* * *}$ & $0.0848 * * *$ & $0.0847 * * *$ \\
\hline Const. Ind. & $0.0195^{* * *}$ & $0.0195 * * *$ & $0.0196 * * *$ & $0.0198 * * *$ \\
\hline Telecom. Ind. & $-0.0281 * * *$ & $-0.0275^{* * *}$ & $-0.0281 * * *$ & $-0.0279 * * *$ \\
\hline Adjusted $\mathrm{R}^{2}$ & $0.0339 * * *$ & $0.0336^{* * * *}$ & $0.0336^{* * *}$ & $0.0334 * * *$ \\
\hline F-Statisic & 39.4403 & 39.1428 & 39.0256 & 38.9039 \\
\hline
\end{tabular}

Note. *** Significant at $1 \%$;* Significant at $5 \%$; $*$ Significant at $10 \%$.

Source: Authors (2014).

The findings from Table 7 reinforce the ascertainments verified previously. It is possible to evaluate that Aud_1 has high significant together with the variable Oth_Aud, respectively 0.0046, and 0.0045, both significant at a level of $10 \%$, revealing that the discretionary behavior of the companies audited by this large firm differs from the other publicly-held entities, resembling the practices adopted by organizations that are served by small audit firms. In relation to the other companies that lead the audit sector, no statistical significance was identified in relation to the individual dummies, and no significance together with the Out-Aud term was found either. However, it is emphasized that all the parameters estimated for Aud_2, Aud_3 and Aud_4 appeared negative (-0.0036, -0.0027 and -0.0002), indicating lower levels of EM in comparison to the others.

Based on the findings assessed in Table 6 and 7, it is possible to accept the hypotheses raised in subsection 2.3. Moving on to $\mathrm{H} 1$, it is emphasized that the verification of differentiated behaviors involving the DAs of Brazilian public companies, corroborated by statistical significances between two of the four largest companies from the audit industry, indicates differentiated EM levels at these organizations, rejecting the supposed uniformity highlighted by the literature, at a tangent to the factors that would lead to the formation of a group once named Big N, as it used to have other participants currently no longer existing due to business defeats. In using DAs as a metric to assess the quality of the audit, it was noted that Aud_1 would denote the worst inhibition of earnings management practices by its clients. While the firm designated Aud_2 would be better placed to mitigate this behavior given the estimated parameters of negative values presented.

With regard to $\mathrm{H} 2$, the results demonstrate that the group formed by the smaller audit firms is comparable to some big four companies, more specifically to Aud_1. The congruity observed between these two factors reinforces the argument that in assessing large companies from the sector as independent work cells, evaluating their client concentrations according to the commercial niche that they serve, rather than as large conglomerates 
with complete freedom to carry out their activities, this would represent a new line of investigation into the true autonomy of audit firms, irrespective of their size.

\section{Conclusions}

The purpose of this study was to evaluate whether discretionary accruals, a substitute for EM, of Brazilian public companies, would denote changes as a consequence of the large audit firm that serves them. This question initially originates from a literary survey pertaining to the topic, which advocates a segregation imposed by the size of audit companies, without taking into account more specific issues of the market in which a company operates or other considerations inherent to the fact that the largest organizations that are world leaders of the audit sector were once more dispersed.

Unlike previous studies, this survey was based on a data survey that demonstrated which auditors were responsible for issuing the opinion on the financial statements, regardless of size and instead taking company name into account. This method made it possible to assess whether the companies theretofore considered of little significance in the branch, had clients which would reveal variances of DAs at levels different from those of each one of the companies conceptualized as Big Four firms. It was deemed appropriate to alter the commercial nomenclatures of each one of these large companies, aiming mainly at the non-attribution of mislead judgments as refers to the qualitative validation of the work carried out by them.

The results denoted that one of the four largest companies revealed clients served with volumes of EM similar to those of small audit firms, enabling the decline of the underlying idea about the existence of an impassable uniformity in the original proposal of DeAngelo (1981) for the Brazilian capital market. Another important finding lies in the verification of the lack of consonance also observed between the four leaders, given that one of these proved to have clients with differentiated behaviors comparing them with the firms served by the others.

As a consequence of these findings, it is suggested that future surveys, which need to control the quality of the audit firm in its approaches, do so through the creation of five groups, one for each large company from the audit sector and the fifth for entities operating in the industry, yet of narrower commercial scope. It is believed that this application enables the observation of more accurate results, above all by inhibiting the concealment of possible biases which could be contained in the traditional dichotomous approach between big $\mathrm{n}$ and others.

\section{References}

Almeida, B. J. M. (2005). Análise comparativa das filosofias de auditoria. Revista de Contabilidade e Finanças USP. http://dx.doi.org/10.1590/S1519-70772005000100007

Balsam, S., Krishnam, J., \& Young, J. (2003). Auditor industry specialization and earnings quality. Auditing: A Journal of Practice and Theory, 22, 71-97. http://dx.doi.org/10.2308/aud.2003.22.2.71

Becker, C. L., Defond, M. L., Jiambalvo, J., \& Subramanyam, K. R. (1998). The effect of audit quality on earnings management. Contemporary Accounting Research. http://dx.doi.org/10.2139/ssrn.436260

Blouin, J., Grein, B., \& Rountree, B. (2007). An analysis of forced auditor change: The case of former arthur andersen clients. The Accounting Review. http://dx.doi.org/10.2308/accr.2007.82.3.621

Borgerth, V. M. C. (2007). SOX: entendendo a Lei Sarbarnes Oxley - Um caminho para informação transparente. São Paulo: Thomson.

Boynton, W. C., Johnson, R. N., \& Kell, W. G. (2002). Auditoria (7th ed.). São Paulo: Atlas.

Carvalho, L. N. G., \& Murcia, F. D. (2007). Conjecturas acerca do gerenciamento de lucros, republicação das demonstrações contábeis e fraude contábil. Contabilidade Vista e Revista. Retrieved from http://web.face.ufmg.br/face/revista/index.php/contabilidadevistaerevista/article/view/340/333

Chambers, R. J. (1999). The Poverty of Accounting Disclosure. Abacus, 35(3), 241-251. http://dx.doi.org/10.1111/1467-6281.00044

Coelho, A. C., \& Lopes, A. B. (2007). Avaliação da prática de gerenciamento de resultados na apuração de lucro por companhias abertas brasileiras conforme seu grau de alavancagem. Revista de Administração Contemporânea. http://dx.doi.org/10.1590/S1415-65552007000600007

DeAngelo, L. (1981). Auditor size and audit quality. Journal of Accounting and Economics. http://dx.doi.org/10.1016/0165-4101(81)90002-1

Dechow, P. M., Sloan, R. G., \& Sweeney, A. P. (1995). Detecting earnings management. The Accounting Review. Retrieved from http://www.jstor.org/stable/248303 
DeFond, M., \& Jiambalvo, J. (1993). Factors related to auditor-client disagreements over income-increasing accounting methods. Contemporary Accounting Research. http://dx.doi.org/10.1111/j.1911-3846.1993.tb00889.x

Diggle, P. J. et al. (2002). Analysis of longitudinal data (2nd ed.). Oxford Univ. Press.

Dopuch, N., \& Simunic, D. (1982). Competition in auditing: An assessment. In Symposium on Auditing Research IV (pp. 401-450). Urbana: University of Illinois.

Duarte, P. C., Lamounier, W. M., \& Takamatsu, R. T. (2007). Modelo econométricos para dados em painel: Aspectos teóricos e exemplos de aplicação à pesquisa em contabilidade e finanças. Congresso USP Controladoria e Contabilidade, São Paulo.

Ebrahim, A. (2001). Audit quality, auditor tenure, client importance, and earnings management: An additional evidence. Retrieved from http://www.papers.ssrn.com/

Fávero, L. P. L. (2013). Dados em painel em contabilidade e finanças: Teoria e aplicação. Brazilian Business Review, 10(1), 131-156.

Fields, T. D., Lys, T. Z., \& Vicent, L. (2001). Empirical research on accounting choice. Journal of Accounting and Economics, 31, 255-307. http://dx.doi.org/10.1016/S0165-4101(01)00028-3

Gioelli, S. O., Carvalho, A. G., \& Sampaio, J. O. (2013). Capital de risco e gerenciamento de resultados em IPOs. Brazilian Business Review, 10(4), 32-68.

Giroux, G. A. (2004). Detecting earnings management. Hoboken, New Jersey.

Healy, P. M., \& Wahlen, J. M. (1999). A review of the earnings management literature and its implications for standard setting. The Accounting Horizons. http://dx.doi.org/10.2139/ssrn.156445

Hirst, E. (1994). Auditors' sensitivity to earnings management. Contemporary Accounting Research. http://dx.doi.org/10.1111/j.1911-3846.1994.tb00449.x

Islam, A., Ali, R., \& Ahmad, Z. (2011). Is modified jones model effective in detecting earnings management? Evidence from a developing economy. International Journal of Economics and Finance. http://dx.doi.org/10.5539/ijef.v3n2p116

Jensen, M., \& Meckling, W. H. (1976). Theory of the firm: managerial behavior, agency costs of and ownership structure. Journal of Financial Economics. http://dx.doi.org/10.2139/ssrn.94043

Jones, J. (1991). Earnings management during import relief investigations. Journal of Accounting Research, 29(2), 193-217. http://dx.doi.org/10.2307/2491047

Jones, K. L., Krishnan, G. V., \& Melendrez, K. D. (2008). Do models of discretionary accruals detect actual cases of fraudulent and restated earnings? An empirical analysis. Contemporary Accounting Research. http://dx.doi.org/10.1506/car.25.2.8

Kang, S., \& Sivaramakrishnan, K. (1995). Issues in testing earnings management and an instrumental variable approach. Journal of Accounting Research. http://dx.doi.org/10.2307/2491492

Kinney, W. R., \& Martin, R. D. (1994). Auditor does auditing reduce bias in financial reporting? A review of audit-related adjustments studies. Auditing: A Journal of Practice \& Theory, 13(Spring), 149-156.

Kothari, S. P., Leone, A. J., \& Wasley, C. E. (2005). Performance matched discretionary accrual measures. Journal of Accounting and Economics. http://dx.doi.org/10.1016/j.jacceco.2004.11.002

Krishnan, G. V. (2003). Audit quality and the pricing of discretionary accruals. Auditing: A Journal of Practice and Theory. http://dx.doi.org/10.2139/ssrn.320164

Larker, D. F., \& Richardson, S. A. (2004). Fees paid to audit firms, accruals choices, and corporate governance. Journal of Accounting Research, 42, 625-658. http://dx.doi.org/10.1111/j.1475-679X.2004.t01-1-00143.x

Marques, L. D. (2000). Modelos dinâmicos com dados em painel: Revisão da literatura. Série Working Papers do Centro de Estudos Macroeconômicos e Previsão (CEMPRE) da Faculdade de Economia do Porto, Portugal, n. 100.

Maureen F. M. (2002). Discussion of The quality of accruals and earnings: The role of accrual estimation errors. The Accounting Review, 77(s-1), 61-69. http://dx.doi.org/10.2308/accr.2002.77.s-1.61

Mcnichols, M. (2000). Research design Issues in earnings management. Journal of Accounting Studies. http://dx.doi.org/10.1016/S0278-4254(00)00018-1 
Meek, G., \& Thomas, W. B. (2004). A review of markets-based international accounting research. Journal of International Accounting Research, 3, 21-41. http://dx.doi.org/10.2308/jiar.2004.3.1.21

Nichols, D. R., \& Smith, D. B. (1983). Auditor credibility and auditor changes. Journal of Accounting Research. http://dx.doi.org/10.2307/2490789

Ohtman, H. B., \& Zeghal, D. (2006). A study of earnings-management motives in the Anglo-American and Euro-Continental accounting models: The Canadian and French cases. The International Journal of Accounting. http://dx.doi.org/10.1016/j.intacc.2006.09.004

Patricia, M. D., \& Dichev, I. D. (2002). The quality of accruals and earnings: The role of accrual estimation errors. The Accounting Review, 77, 35-59. Retrieved from http://www.jstor.org/stable/3203324

Patricia, M. D., Richardson, S. A., \& Tuna, I. (2003). Why are earnings kinky? An examination of the earnings management explanation. Review of Accounting Studies, 8(2), 355-384. http://dx.doi.org/10.1023/A:1024481916719

Riahi-Belkaoui, A. (2005). Accounting theory. London: Thomson.

Sahay, S., ZviDavis, H., \& Peikes, M. (2012). Earnings management and auditor quality. Accounting and Finance Research, 1(1), 38-52. http://dx.doi.org/10.5430/afr.v1n1p38

Schipper, K. (1989). Earnings management. The Accounting Horizons, 3(4), 91-102.

Scott, W. R. (2003). Financial accounting theory (3rd ed.). Toronto: Prentice Hall.

Teoh, S. H., \& Wong, T. J (1993). Perceived auditor quality and the earnings response coefficient. The Accounting Review. Retrieved from http://www.jstor.org/stable/248405

Tie, R. (1999). Concerns over auditing quality complicate the future of accounting. Journal of Accountancy, 188(6), 14-15.

Wallace, W. (1980). The economic role of the audit in free and regulated markets. The Touche Ross and Co. Aid to Education Program. Reprinted in Auditing Monographs. Retrieved from http://raw.rutgers.edu/raw/wallace/homepage.html

Wang, X., \& Yang, B. (2012). International differences between big four auditors and their smaller counterparts in monitoring earnings management. International Journal of Accounting and Financial Reporting. http://dx.doi.org/10.5296/ijafr.v2i2.2086

Watts, R. L., \& Zimmermam, J. L. (1978). Towards a positive theory of determination of accounting standards. The Accounting Review, 53, 112-134.

Wooldridge, J. M. (2010). Introdução à econometria: uma abordagem moderna (4th ed.). São Paulo, CENGAGE Learning.

Yale, C., \& Forsythe, A. B. (1976). Winsorized regression. Technometrics, 18, 291-300. http://dx.doi.org/10.1080/00401706.1976.10489449

\section{Copyrights}

Copyright for this article is retained by the author(s), with first publication rights granted to the journal.

This is an open-access article distributed under the terms and conditions of the Creative Commons Attribution license (http://creativecommons.org/licenses/by/3.0/). 